\title{
THE ROLE OF MOTIVATION AS MEDIATION IN IMPROVING EMPLOYEE PERFORMANCE OF THE GOVERNMENT OF SURABAYA CITY EAST JAVA
}

\author{
Sumiati Sumiati \\ Faculty of Economics and Business Universitas 17 Agustus 1945 Surabaya, Indonesia \\ Email: Sumiatife@untag-sby.ac.id
}

\begin{abstract}
This paper discussed the causal relationship between servant leadership, professionality, work culture, motivation, and the performance of Surabaya City Government employees. One model was proposed to verify the role of motivation as a mediating variable in the indirect relationship of servant leadership, professionality, work culture and performance. The population was the government employees of Surabaya City. Analysis by SEM, on 290 respondents, used the convenience sampling method. The results showed that the model was accepted, and also showed that servant leadership, professional, and work culture had an effect on motivation. Servant leadership, work culture and motivation had an effect on employee performance. Motivation was a positive mediating variable in the relationship between servant leadership, professional, and work culture with performance.
\end{abstract}

Keywords: Servant leadership, professionalism, work culture, motivation, employee performance.

\section{Introduction}

Leaders who are able to form a work atmosphere and culture that encourage employee growth and development are successful leaders. A superior leader has the ability to develop a positive influence on his members and do the work as desired to achieve the goals set. The leadership factor plays a very important role in improving employee performance because effective leadership provides direction to the efforts of all employees in achieving organizational goals. To be able to improve employee performance to the maximum, the leader can apply an effective leadership style so that employee performance increases and organizational goals are achieved (Sedarmayanti, 2017). One good guideline for improving employee performance is to adopt a leadership style that builds motivation.

The leader's job is to serve. The best leaders are the best servants (Sedarmayanti, 2017). The new leadership model is a leadership model that seeks to simultaneously increase the personal growth of employees, and improve the quality of organizational services on community development. This is done through a combination of teamwork, and caring and ethical behavior. This leadership concept is called servant leadership. Harwiki (2013), proves that servant leadership influences motivation, organizational culture, and employee performance. Meanwhile, Koesmono (2014) compares a servant leadership relationship to employee performance.

To support the achievement of organizational goals, professional and well-performing employees are needed. Employee professionalism is the basic ability of someone who has special expertise in a particular field in carrying out their duties and obligations with a full sense of responsibility. Futri and Juliarsa (2014) and Rahayuningsih (2012) showed that there was a relationship between professionalism and performance. Optimal employee performance can also provide benefits to the organization in terms of work that will be quickly resolved, damage reduced, and attendance minimized. Therefore, organizational leaders need to pay attention to circumstances that affect employee performance.

The influence of work motivation on performance is proven by Habba, Modding, Bim, and Bijan (2017). Employee's work motivation at a high level is shown to improve employee performance. Meanwhile, Harwiki (2013) showed the effect of servant leadership on employee motivation and performance. Sugiarti, Suntoro, and Nurmalisa (2015) proved that there was a relationship between work motivation on employee performance and work culture on employee performance.

Work culture is a group of basic thoughts or mental programs that can be used to increase work efficiency and employee cooperation (Ndraha, 2012). Arianto (2013) proved the existence of a relationship among work culture and performance. Motivation is the drive, effort, and desire that exists in humans that activate, empower, and direct behavior to carry out tasks well in the scope of work (Hakim, 2006). Robbins (2008) defined motivation as a process that helps determine the intensity, direction, and persistence of an individual in achieving goals. Cahyono and Suharto (2005) and Hakim (2006) showed the influence of work motivation on performance. 
A person's performance is a combination of abilities, efforts and opportunities that can be assessed from the results of his work. Bernardin and Russel (2003) stated that performance was the recording of a job at one particular time. Robbins (2008) stated that performance was the willingness of a person or group of people to do an activity and perfect it according to their responsibilities with the expected results. According to Effendy (2018) performance was executed and its output was the result of the employees behavior displayed within their role in the organization.

Performance can be defined as the results and outputs of an employee produced in accordance with his support at the organization and at one time. One of the main factors in increasing productivity is employee performance. Performance is an indicator in determining how efforts are achieved at high levels of productivity in an organization.

The city of Surabaya is the capital of the province of East Java, which has the highest number of employees, amounting to 14,220 (BPS Provinsi Jawa Timur, 2019), so that the Surabaya City Government is an example and role model for others city and district governments in East Java Province.

From some of the explanations above, it can be concluded that motivation will arise as a result of the trigger (servant leadership, professionalism, and work culture), and motivated employees will carry out their duties and responsibilities optimally. Therefore, this study is conducted to get a better understanding of the relationship between motivation and employee performance in the Surabaya City Government, and to chek the role of motivation as a mediating variable in the relationship among servant leadership, professionalism, and work culture on employee performance, which is a moderator in this research.

\section{Servant Leadership}

Servant leadership provides a framework that encourages many individuals to be able to provide assistance in improving the way of treating other parties who work in various organizations. Servant leadership is a leadership model that tries to simultaneously increase employee personal growth and improve organizational service quality through a combination of teamwork and community development, personal involvement in the decision-making process, and caring and ethical behavior (Sedarmayanti, 2017).

The characteristics of servant leadership are (Patterson \& Purkey, 1993):

- Love: Leaders do something good for the right reasons at the right time;
- Humble: The ability to maintain a balance between possessions and the awareness that what the leader has achieved can happen because of the abilities and contributions of the followers, not because of themselves;

- Altruism: The act of helping others sincerely;

- Having a Vision: The leader builds the organization's vision through the visions of the followers in the aggregate;

- Trust: Followers believe that workers in organizations with servant leadership will lead to achieving the follower's vision;

- Empowering others: Entrusting power to the other party, then declaring it. Make each follower feel meaningful, important to the organization and his work, emphasize teamwork, value love and equality;

- Serving: Service must be the main function of leadership, not based on self-interest but more directed at the interests of followers and the organization.

Lestari, Florentinus, and Sudana (2019) showed that the leadership of the principal affects teacher motivation, and there was an effect of incentives on teacher motivation. Chen, Chen, and Li (2013) showed that spiritual values perceived by subordinates, as well as differences between leader or subordinate perceptions contribute significantly in predicting subordinates' motivational autonomy. Su, Lyu, Chen, and Zhang, (2020) and Harwiki (2013) proved that servant leadership had an effect on employee motivation, culture, and performance. Khan, Khan, and Zeeshan (2016) proved that there was a relationship between servant leadership style and worker motivation. Based on this description, the following hypothesis is proposed:

$H_{1}$ : Servant leadership has a significant effect on employee motivation at the Surabaya City Government.

Kaminska (2016) showed a positive relationship between servant leadership and positive work results, such as job autonomy and job satisfaction. Muhtasom, Mus, Bijang, and Latief (2017) and Dalimunthe (2002) concluded that leadership style affected employee performance. Sihombing, Astuti, Al Musadieq, Hamied, and Rahardjo (2018), Yumte, Rante, Ronsumbre, and Ratang (2017), Muafi and Azim (2019), and Goh and Low (2014) showed that servant leadership had an effect on employee performance. Eliyana, Ma'arif, and Muzakki (2019) proved that transformational leadership could not have a direct 
impact on performance. Chinomona, Mashiloane, and Pooe (2013) showed that servant leadership had a positive effect on employee trust in leaders. Saleem, Zhang, Gopinath, and Adeel (2020) showed that servant leadership strongly predicted affective trust and subordinate task performance. Based on this description, the following hypothesis is proposed:

$\mathrm{H}_{2}$ : Servant leadership has a significant effect on employee performance in the Surabaya City Government.

\section{Professionalism}

Professionalism is the basic ability of someone who has special expertise in certain fields in carrying out their duties and obligations with a full sense of responsibility. Professionalism is to provide services in accordance with the field of knowledge that is owned and fully humane without considering personal interests respecting clients as respecting oneself (Purwandari, 2008). Meanwhile, Siagian (2013) stated that professionalism was measured in terms of its speed in carrying out functions and refered to simplified procedures. Several elements to build professionalism, namely: systems approach, carrying out ethical business practices, development of professional ethics, enforcement through the application of sanctions by professional associations, government policy in the system, exemplary.

Permanasari, Setyaningrum, and Sundari (2014) showed a relationship between professionalism and performance, and there was a relationship between worker motivation and performance. Shishigu (2015) stated that poor teacher motivation was due to very bad salaries, apart from salaries and allowances. Low teacher motivation was due to the inability of school management and administration to effectively met teacher demands for supportive and fair leadership. Matheus (2018) and Popescu, Bulei, and Mihalcioiu (2014) proved a significant correlation between professional identity and motivation. Based on this description, the following hypothesis is proposed:

$H_{3}$ : Professionalism has a significant effect on employee motivation in the Surabaya City Government.

\section{Work Culture}

Work culture can be defined as a combination of the basic ideas of mental programs used in improving organizational cooperation and work efficiency (Ndraha, 2012). Work culture can be divided into: Attitudes towards work, namely a liking for work compared to other activities, or simply obtaining satisfaction from the busyness of one's own work. Behaviors such as being diligent, dedicated, responsible, careful, conscientious, careful, strong willingness to learn their duties and obligations, and like to help fellow employees.

According to Robbins (2008), the factors that influence work culture are: (1) innovation and taking risks, (2) attention to detail, (3) results orientation, (4) human orientation, (5) team orientation, (6) aggressiveness, (7) stability. Al-Sada, Al -Esmael, and Faisal (2017), Virgana (2020), and Sugiarti et al. (2015) stated that work culture affects employee behavior and motivation. This means that employees who are highly motivated will try their best to carry out their duties and responsibilities. So it is necessary to apply a work culture that functions as an element that can affect the effectiveness and stimulate employee motivation to achieve work goals. Based on this description, the following hypothesis is proposed:

$H_{4}$ : Work culture has a significant effect on employee motivation in the Surabaya City Government.

Baker (2002) stated that organizational effectiveness has increasingly emphasized the importance of culture in motivating and maximizing asset value. Sugiarti et al. (2015) showed that work culture and work motivation have an effect on employee performance. Kotter and Heskett (1997) showed that community culture has a strong impact on community work performance. Community culture will increase the success or failure of performance. Arianto (2013) proved the influence of work culture in the performance of teaching staff. Sinha, Singh, Gupta, and Dutt (2010) also proved the influence of work culture on motivation and performance. Based on this description, the following hypothesis is proposed:

$H_{5}$ : Work culture has a significant effect on employee performance in the Surabaya City Government.

\section{Motivation}

Motivation is a process and force that creates excitement for an employee and injects satisfaction for an individual with in his organization (Terry, 2003). Motivation is a process as the initial step for someone to take action due to physical and psychological deficiencies, or in other words, an encouragement that is shown to fulfill certain goals. According to Gibson (2013), motivation theory consisted of content theories that focused on factors in people that reinforced, directed, supported, and stopped the behavior. Meanwhile process theory describes and analyzes how 
behavior is strengthened, directed, supported, and stopped. Both of these categories have an important influence on managers to motivate employees. Giving attention, providing appropriate rewards, and providing promotions for employees who excel can also motivate employees.

McClelland (1987) argued that employees had potential energy reserves. This energy is utilized by employees because it is driven by the motivational power and basic needs involved, the hope of success, and the incentive value attached to the goal. McClelland categorizes three human needs that can motivate a person's passion for work, namely: Need for Achievement; Need for Affiliation, and Need for Power. A person is considered to have the motivation to excel if he has the desire to do a job that is better than the achievements of other people's work. Thus, if someone's needs are very strong, then the impact is that the person will feel motivated to achieve those needs. Therefore, leaders must have a deep understanding of the wants and needs of employees. Purwanta and Nawangsari (2018) and Arofiq (2020) defined motivation was primarily concerned with goal-directed behavior. Therefore, satisfaction and motivation are related. Based on this description, the following hypothesis is proposed:

$H_{6}$ : Motivation has a significant effect on employee performance in the Surabaya City Government.

\section{Research Framework}

Based on the literature review and discussion previously described, a research framework can be developed that explains the relationship between research variables. Figure 1 illustrates the relationship between servant leadership, professionalism, work culture, and motivation on employee performance in the city government of Surabaya, East Java.

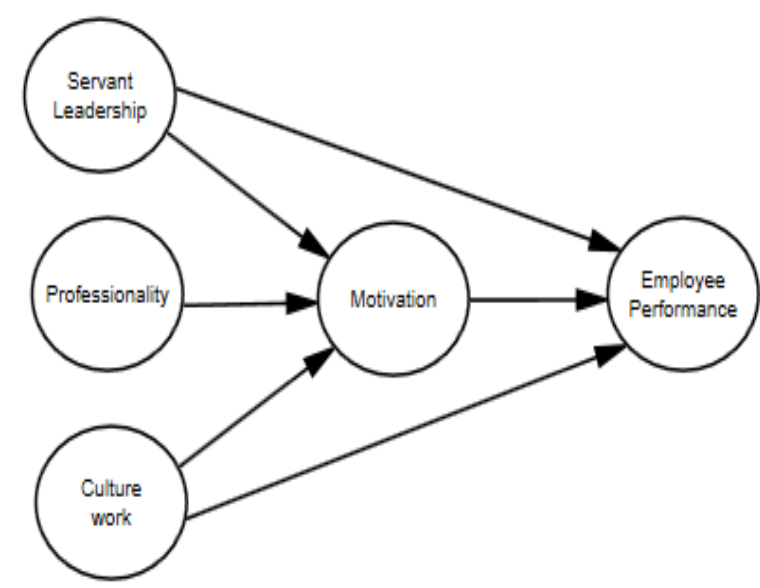

Figure 1. Research framework

\section{Research Methods}

This research is a causal research. The study population was employees of the Surabaya City government, East Java. The analysis technique uses Structural Equation Modelling (SEM) analysis with the help of Amos 24 software. Estimation uses Generalized Least Square Estimation, and the number of samples studied is 290 respondents, obtained from $(28+1) \times 10$ research indicators, in accordance with the provisions of SEM (Hair, Anderson, Tatham, \& Black, 2014). This study took samples using the convenience sampling method.

The study used a questionnaire instrument where servant leadership uses seven indicators adopted from Sedarmayanti (2017), Professionalism uses six indicators adopted from Purwandari (2008), Work culture uses six indica-tors adopted from Robbins (2008), Motivation uses three indicators adopted from McClelland (1987), and employee performance using six indicators adopted from Robbins (2008).

\section{Results and Discussion}

Descriptive data analysis of 290 respondents showed the following results: Characteristics of respondents according to gender showed that male respondents were $60.7 \%$, and female respondents were $39.3 \%$. Characteristics of respondents based on age indicate that respondents aged 17-30 years are $26.3 \%$. The dominant respondent in the age range $31-40$ years was $53.7 \%$. The education level of the majority of respondents was undergraduate as much as $51.0 \%$, diploma education as much as $40.0 \%$, and high school education as much as $9.0 \%$. Employee tenure is in the range of 1-2 years as much as $23.1 \%$, less than one year, $7.6 \%, 3-5$ years, $29.3 \%$, and more than five years as much as $40.0 \%$.

Table 1

Characteristics of respondents $(N=290)$

\begin{tabular}{llrc}
\hline \multicolumn{2}{c}{ Characteristics } & Frequency & Percent \\
\hline Gender & Men & 176 & 60.7 \\
& Women & 114 & 39.3 \\
Age (years) & $17-30$ & 76 & 26.3 \\
& $31-40$ & 156 & 53.7 \\
& $41-58$ & 58 & 20.0 \\
Level of & High school & 26 & 9.0 \\
education & Diploma & 116 & 40.0 \\
& College & 148 & 51.0 \\
& Graduate & & \\
Employee & less than 1 & 22 & 7.6 \\
Tenure (years) & $1-2$ & 67 & 23.1 \\
& $3-5$ & 85 & 29.3 \\
& more than 5 & 116 & 40.0 \\
\hline
\end{tabular}




\section{Instrument Validity and Reliability Test}

From the results of the Pearson correlation it is known that all the items in the questionnaire have a significant correlation at an alpha of $5 \%$, so it can be said that all question items are valid. The Cronbach alpha $(\alpha)$ test shows that all research variables are reliable, because all the alpha coefficient values of each research variable are greater than the standard $(0.6)$, so that each question item on the measurement instrument can be used. The total corrected item correlation value of all question items is greater than 0.3 .

Table 2

Validity and Reliability Test

\begin{tabular}{|c|c|c|c|}
\hline $\begin{array}{l}\text { Research } \\
\text { Variables }\end{array}$ & Indicator & $\begin{array}{c}\text { Pearson } \\
\text { correlation }\end{array}$ & $\begin{array}{l}\text { Coefficient } \\
\text { Alpha }(\alpha)\end{array}$ \\
\hline \multirow[t]{6}{*}{ Servant leadership } & SER1 & $0.800^{* * *}$ & 0.800 \\
\hline & SER2 & $0.650 * *$ & \\
\hline & SER3 & $0.808 * *$ & \\
\hline & SER4 & $0.667 * *$ & \\
\hline & SER5 & $0.793 * *$ & \\
\hline & SER6 & $0.744 * *$ & \\
\hline \multirow[t]{6}{*}{ Professionality } & SER7 & $0.609 * *$ & \\
\hline & PRO1 & $0.711 * *$ & 0.711 \\
\hline & PRO2 & $0.667 * *$ & \\
\hline & PRO3 & $0.879 * *$ & \\
\hline & PRO4 & $0.657 * *$ & \\
\hline & PRO5 & $0.707 * *$ & \\
\hline \multirow[t]{6}{*}{ Work Culture } & PRO6 & $0.832 * *$ & \\
\hline & BUD1 & $0.717 * *$ & 0.893 \\
\hline & BUD2 & $0.710 * *$ & \\
\hline & BUD3 & $0.812 * *$ & \\
\hline & BUD4 & $0.721 * *$ & \\
\hline & BUD5 & $0.677 * *$ & \\
\hline \multirow[t]{3}{*}{ Motivation } & BUD6 & $0.877 * *$ & \\
\hline & MOV1 & $0.757 * *$ & 0.744 \\
\hline & MOV2 & $0.727 * *$ & \\
\hline Employee & MOV3 & $0.822 * *$ & \\
\hline \multirow[t]{6}{*}{ Performance } & KIN1 & $0.718 * *$ & 0.782 \\
\hline & KIN2 & $0.816^{* *}$ & \\
\hline & KIN3 & $0.723 * *$ & \\
\hline & KIN4 & $0.679 * *$ & \\
\hline & KIN5 & $0.878 * *$ & \\
\hline & KIN6 & $0.772 * *$ & \\
\hline
\end{tabular}

**. Correlation is significant at the 0.01 level (2-tailed).

\section{Confirmatory Factor Analysis}

Table 3 shows the overall results of the confirmatory factor analysis of the research measurement model. The validity and reliability of constructs are two tests to evaluate the ability of the measured variable (manifest) to form latent variables, in the table below all manifest has a loading factor with a probability of less than 0.05 , meaning that it is significant in forming latent variables. It can also be seen that each latent variable has a construct critical ratio of more than 0.2 , which means that it comes from one dimension (unidimensional).
Table 3

Confirmatory Factor Analysis

\begin{tabular}{|c|c|c|c|}
\hline Relationship & C. $\mathbf{R}$. & $\begin{array}{c}\text { Loading } \\
\text { Factor }(\lambda)\end{array}$ & $\begin{array}{c}\text { Probabi } \\
\text { lity }\end{array}$ \\
\hline$\overline{\text { SER }} \rightarrow$ SER1 & 2.000 & 0.676 & 0.000 \\
\hline $\mathrm{SER} \rightarrow \mathrm{SER} 2$ & 3.603 & 0.552 & 0.000 \\
\hline $\mathrm{SER} \rightarrow \mathrm{SER} 3$ & 7.711 & 0.699 & 0.000 \\
\hline SER $\rightarrow$ SER4 & 6.040 & 0.518 & 0.000 \\
\hline SER $\rightarrow$ SER5 & 3.983 & 0.534 & 0.000 \\
\hline SER $\rightarrow$ SER6 & 3.824 & 0.554 & 0.000 \\
\hline $\mathrm{SER} \rightarrow \mathrm{SER} 7$ & 3.953 & 0.508 & 0.000 \\
\hline PRO $\rightarrow$ PRO1 & 2.000 & 0.508 & 0.000 \\
\hline $\mathrm{PRO} \rightarrow \mathrm{PRO} 2$ & 8.618 & 0.853 & 0.000 \\
\hline $\mathrm{PRO} \rightarrow \mathrm{PRO} 3$ & 7.711 & 0.725 & 0.000 \\
\hline $\mathrm{PRO} \rightarrow \mathrm{PRO} 4$ & 6.042 & 0.463 & 0.000 \\
\hline $\mathrm{PRO} \rightarrow \mathrm{PRO} 5$ & 7.557 & 0.655 & 0.000 \\
\hline $\mathrm{PRO} \rightarrow \mathrm{PRO} 6$ & 7.805 & 0.728 & 0.000 \\
\hline BUD $\rightarrow$ BUD1 & 2.000 & 0.884 & 0.000 \\
\hline BUD $\rightarrow$ BUD2 & 13.717 & 0.746 & 0.000 \\
\hline BUD $\rightarrow$ BUD3 & 7.711 & 0.740 & 0.000 \\
\hline BUD $\rightarrow$ BUD4 & 10.451 & 0.610 & 0.000 \\
\hline BUD $\rightarrow$ BUD5 & 13.627 & 0.461 & 0.000 \\
\hline BUD $\rightarrow$ BUD6 & 2.704 & 0.778 & 0.000 \\
\hline MOV $\rightarrow$ MOV1 & 2.000 & 0.610 & 0.000 \\
\hline $\mathrm{MOV} \rightarrow \mathrm{MOV} 2$ & 5.815 & 0.884 & 0.000 \\
\hline $\mathrm{MOV} \rightarrow \mathrm{MOV} 3$ & 9.550 & 0.746 & 0.000 \\
\hline $\mathrm{KIN} \rightarrow \mathrm{KIN} 1$ & 2.000 & 0.478 & 0.000 \\
\hline $\mathrm{KIN} \rightarrow \mathrm{KIN} 2$ & 2.263 & 0.796 & 0.000 \\
\hline $\mathrm{KIN} \rightarrow \mathrm{KIN} 3$ & 2.900 & 0.740 & 0.000 \\
\hline $\mathrm{KIN} \rightarrow \mathrm{KIN} 4$ & 2.875 & 0.664 & 0.000 \\
\hline $\mathrm{KIN} \rightarrow \mathrm{KIN} 5$ & 2.657 & 0.524 & 0.000 \\
\hline KIN $\rightarrow$ KIN6 & 2.590 & 0.778 & 0.000 \\
\hline
\end{tabular}

SER: Servant Leadership, PRO: Professionality, CUL: Work Culture, MOT: Motivation, EMP: Employee Performance, CR: Critcal Ratio, P: Probability.

\section{Goodness of Fit Test}

The results of data processing using a sample of 290 shows that the Chi-square is 257,532 with a probability of 0.051 . Meanwhile, GFI, AGFI, TLI, CFI, RMSEA and CMIN / DF respectively 0.913, $0.904,0.951,0.953$, and 0.068 are all in the acceptable value ranges.

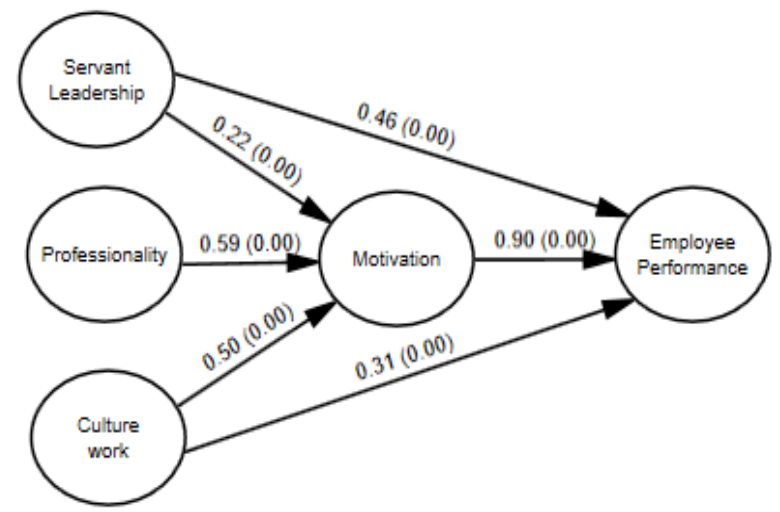

Figure 2. Coefficient of research model path 


\section{Hypothesis testing}

Hypothesis testing is carried out based on the estimated value of the significance of the research model parameters shown in Table 4.

Table 4

Hypothesis Testing

\begin{tabular}{lcccc}
\hline Relationship & Coefficient & $\boldsymbol{C . R}$. & $\boldsymbol{P}$ & Decision \\
\hline SER $\rightarrow$ MOT & 0.224 & 2.092 & 0.000 & accepted \\
SER $\rightarrow$ EMP & 0.460 & 4.433 & 0.000 & accepted \\
PRO $\rightarrow$ MOT & 0.586 & 5.094 & 0.000 & accepted \\
CUL $\rightarrow$ MOT & 0.499 & 4.147 & 0.000 & accepted \\
CUL $\rightarrow$ EMP & 0.315 & 2.272 & 0.006 & accepted \\
MOT $\rightarrow$ EMP & 0.898 & 8.691 & 0.000 & accepted \\
\hline
\end{tabular}

The results of the study are in accordance with the findings of Rahayuningsih (2012) and Permanasari et al. (2014). Work culture has a significant effect on employee motivation in the Surabaya City Government. This shows that a high work culture will encourage employee motivation to increase. A work culture consisting of innovation and taking risks, attention to details, results orientation, human orientation, team orientation, aggressiveness, and stability, if implemented properly and always improved, employee motivation will increase. The results of the study are in accordance with the findings of Giantari and Riana (2017) and Sinha et al. (2010). Work culture has a significant effect on employee performance in the Surabaya City Government. This shows that with a high work culture, it will encourage increased employee performance. The results of the study are in accordance with the findings of Sugiarti et al. (2015) and Sinha et al. (2010). Work motivation has a significant effect on employee performance. This shows that high work motivation will encourage employee performance in the Surabaya City Government, East Java. The results of the study are in accordance with the findings of Sugiarti et al. (2015) and Permanasari et al. (2014).

Of the three variables (servant leadership, professionalism, and work culture), which are hypothesized to affect motivation, the dominant one is the value of professionalism. This shows that the proportionality of employees is very important to be able to increase employee motivation. Therefore, the leadership of the organization should increase the proportionality of employees, so that employees have the necessary knowledge in carrying out their duties, have the necessary skills, and always behave professionally. Of the three variables (servant leadership, work culture, and motivation), which are hypothesized to affect employee performance, the dominant one is the value of motivation. This shows that employee motivation is very important to be able to improve employee performance. Therefore, the leadership of the organization should increase employee motivation. So that employees have the desire to do a work that has a better performance than the achievements of other people's work. Employees also need affiliation and a need for power. These three needs prove to be very important elements in determining one's performance. Thus, if the need for employees is very strong, then the impact is that the employee will feel motivated to achieve their needs. Therefore, leaders must have a deep understanding of the wants and needs of employees.

Table 5

\section{Relationship between Variables}

\begin{tabular}{lccc}
\hline Relationship & $\begin{array}{c}\text { Direct } \\
\text { Effects }\end{array}$ & $\begin{array}{c}\text { Indirect } \\
\text { Effects }\end{array}$ & $\begin{array}{c}\text { Total } \\
\text { Effects }\end{array}$ \\
\hline SER $\rightarrow$ MOT & 0.224 & 0.000 & 0.224 \\
SER $\rightarrow$ EMP & 0.460 & 0.221 & 0.681 \\
PRO $\rightarrow$ MOT & 0.586 & 0.000 & 0.586 \\
PRO $\rightarrow$ EMP & 0.000 & 0.579 & 0.579 \\
CUL $\rightarrow$ MOT & 0.499 & 0.000 & 0.499 \\
CUL $\rightarrow$ EMP & 0.315 & 0.493 & 0.808 \\
MOT $\rightarrow$ EMP & 0.898 & 0.000 & 0.898 \\
\hline
\end{tabular}

The results of statistical analysis in Table 5 show that there is an indirect relationship between servant leadership, professionality, work culture variables and employee performance variables. This proves that employee motivation is a good moderator variable between servant leadership, professionality, work culture and employee performance in the Surabaya city government, East Java.

\section{Conclusions and Suggestions}

The results of the study prove that the variables servant leadership, professional, and work culture has an effect on motivation, and variables servant leadership, work culture, and motivation have an effect on employee performance. The results of the study have proven that employee motivation is a good mediating variable in the relationship between servant leadership, professional, and work culture variables on employee performance. It also proves that proportionality is the dominant variable that affects employee motivation.

The research implication is that leaders can motivate subordinates, especially in relation to behavior directed at organizational goals. This can be done by providing appropriate and fair rewards, as well as providing promotions for high performing employees. Further research is suggested to examine further the effect of servant leadership, professionalism, work 
culture and motivation on employee performance by adding other variables such as work environment, support from coworkers and other variables. Also by using other indicators and expanding the scope of the research area.

\section{References}

Al-Sada, M., Al-Esmael, B. \& Faisal, M. N. (2017). Influence of organizational culture and leadership style on employee satisfaction, commitment and motivation in the educational sector in Qatar. EuroMed Journal of Business, 12(2), 163-188.

Arianto, D. A. N. (2013). Pengaruh kedisiplinan, lingkungan kerja dan budaya kerja terhadap kinerja tenaga pengajar. Jurnal Economia, 9 (2), 191199.

Arofiq, A. (2020). Effect of work culture on performance through work motivation: Study in teachers of public senior high schools in Mataram city. International Journal of Social Sciences, 3(1), 71-79. https://doi.org/10.3 12 95/ijss.v3n1.154

Baker, K. A. (2002). Organizational culture. Retrieved from http://www.au.af.mil/au/aw c/awcgate/doe/ benchmark/11-Organization alCulture

Bernardin, H. J., \& Russel, E. A. (2003). Human resource management: An experiential approach. Singapore: McGraw-Hill.

BPS Provinsi Jawa Timur (2019). Jumlah pegawai negeri sipil menurut kabupaten kota dan jenis kelamin di provinsi Jawa Timur 2018-2019. Retrieved from https://jatim.bps.go.id/statictable/ 2019/10/09/1630/jumlah pegawai negeri sipil menurut kabupaten kota dan jenis kelamin di provinsi jawa timur 2018-2019.html

Cahyono, B., \& Suharto (2005). The influence of organizational culture, leadership and work motivation on human resources performance at the DPRD Secretariat of Central Java Province. Jurnal Riset Bisnis Indonesia, 1, 24-32.

Chen, C. Y., Chen, C. H. V., \& Li, C. I. (2013). The influence of leader's spiritual values of servant leadership on employee motivational autonomy and eudaemonic well-being. Journal of Religion and Health, 52(2), 418-438. https://doi.org/10. 1007/s10943-011-94 79-3

Chinomona, R., Mashiloane, M., \& Pooe, D. (2013). The influence of servant leadership on employee trust in a leader and commitment to the organization. Mediterranean Journal of Social Sciences, 4(14), 405-414.

Dalimunthe, R. F. (2002). Pengaruh karakteristik individu, kewirausahaan, gaya kepemimpinan terhadap kemampuan usaha serta keberhasilan usaha industri kecil tenun dan bordir di Sumatera Utara, Sumatera Barat dan Riau. Retrieved from http://repository.un air.ac.id/ 32347

Effendi, U. (2018). Asas Manajemem. Edisi Kedua. Depok: PT. RajaGrafindo Persada.

Eliyana, A., Ma'arif, S., \& Muzakki (2019). Job satisfaction and organizational commitment effect in thetransformational leadership towards employee performance. European Research on Managemen tand Business Economics, 25, 144 150.

Futri, P. S., \& Juliarsa, G. (2014). The influence of independence, professionalism, education level, professional ethics, experience, and job satisfaction of auditors on audit quality of public accounting firms in Bali. Jurnal Akuntansi Universitas Udayana, 7(2), 444-4460.

Gibson (2013). Penilaian kinerja. Jakarta: Penerbit Erlangga.

Giantari, I. A. I., \& Riana, I. G. (2017). The influence of organizational culture on work motivation and performance of Klumpu Bali Resort Sanur Employees. Jurnal Manajemen Unud, 6(2), 471-498.

Goh, S. K., \& Low, B. Z. J. (2014). The Influence of servant leadership towards organizational commitment: The mediating role of trust in leaders. International Journal of Business and Management, 9(1), 17-25.

Habba, D., Modding, B., Bima, M. J., \& Bijang, J. (2017). The effect of leadership, organisational culture and work motivation on job satisfaction and job performance among civil servants in Maros District Technical Working Unit. International Journal of Management \& Social Sciences, 7(1), 52-64.

Hakim, A. (2006). Analysis of the influence of motivation, organizational commitment and organizational climate on employee performance at the transportation and telecommunications office of Central Java Province. Jurnal Riset Bisnis Indonesia, 2(2), 165-180.

Hair, J. F., Anderson, R. E., Tatham, R. L., \& Black, W. C. (2014). Multivariate data analysis. $6^{\text {th }}$ Edition. Upper Saddle River, New Jersey, NJ: Prentice-Hall, Inc.

Harwiki, W. (2013). Influence of servant leadership to motivation, organization culture, organizational citizenship behavior, and employee's performance in outstanding cooperatives East Java Province, Indonesia. IOSR Journal of Business and Management 8(5), 50-58 
Kaminska, M. (2016). Servant leadership and experience of job satisfaction and job autonomy among residents of small Icelandic town. Retrieved from https://skemman.is/bitstre am/1946/26182/1/MartaKaminska_BS_lokaver k.pdf

Khan, A., Khan, A. U., \& Zeeshan, M. (2016). Consequences of servant leadership style on employees' motivation (Empirical study on private and public sector universities employees). Journal of Applied Environmental and Biological Sciences, 6(5S),124-138.

Koesmono, H. T (2014). The influence of organizational culture, servant leadership, and job satisfaction toward organizational commitment and job performance through work motivation as moderating variables for lecturers in economics and management of private universities in East Surabaya. Educational Research International, 3(4), 25-39

Kotter, J. P., \& Heskett, J. L. (1997). Corporate culture and performance. New York, NY: The Free Press.

Lestari, S., Florentinus, T. S., \& Sudana, I. M. (2019). The effect of incentive, principal leadership, and motivation toward teacher professionalism in conducting learning activity at vocational high schools. Educational Management, 8(1), 34-43.

Matheus, E. (2018). Pengaruh profesionalisme, kepuasan kerja, motivasi, dan lingkungan kerja terhadap kinerja pemeriksa pajak (Studi pada pemeriksa pajak KPP Pratama Bangkinang, KPP Pekanbaru Senapelan, KPP Pratama Pekanbaru Tampan, dan KPP Madya Pekanbaru) Jurnal Online Mahasiswa Fakultas Ekonomi dan Bisnis, Universitas Riau, 1(1), 1-14.

McClelland, D. C. (1987). Human motivation. New York, NY: Cambridge University Press.

Muafi, M., \& Azim, M. (2019). The effect of servant leadership, organizational culturein employee performance mediated by job satisfaction (Study case of Al-Kahfi Islamic Boarding School, Somalangun, Kebumen). Presented in the $13^{\text {th }}$ International Quality Conference.

Muhtasom, A., Mus, H. A. R, Bijang, J., \& Latief, B. (2017). Influence of servant leadership, organizational citizenship bahaviour on organizational culture and employee performance at Star Hotel in Makassar. International Journal of Education and Research, 5(10), 71-88.

Ndraha, T. (2012). Introduction to human resource development theory. Jakarta: Rineka Cipta.
Patterson, C. H., \& Purkey, W. W. (1993). The preparation of humanistic teachers for next century schools. The Journal of Humanistic Education and Development, 31(4), 147-155. https://doi. org/10.1002/j.2164-4683 19 93.tb 00078. $\mathrm{x}$

Permanasari, R., Setyaningrum, R.M, \& Sundari, S. (2014). Relationship model between competence, professionalism and performance teaching. Jurnal Bisnis, Manajemen \& Perbankan, 1(2), 157-174

Popescu, D. M., Bulei, L., \& Mihalcioiu, V. (2014). The impact of professional identity factors on employee motivation. Proceedings of the $8^{\text {th }}$ International Management Conference "Management Challenges for Sustainable Development", November 6th-7th, 2014, Bucharest, Romania

Purwandari, A. (2008). Konsep kebidanan sejarah dan profesionalisme. Jakarta: EGC.

Purwanta, F. F., \& Nawangsari, L. C. (2018). The influence of work motivation, organiza-tional culture, and work environment on the work discipline of employees of PT Inti Karya Persada Tehnik. International Journal of Scientific and Research Publications, 8(12), 86-92.

Rahayuningsih, S. (2012). Analysis of the influence of professionalism on organizational commitment, job satisfaction, job performance and desire to change for professional nurses (Study at Sultan Agung Islamic Hospital Semarang). Conference in Business, Accounting, And Management, 1(3), 41-46.

Robbins, S. P. (2008). Organizational behavior $\left(9^{\text {th }}\right.$ Edition), New York, NY: Prentice Hall International.

Saleem, S., Zhang, Y. Z., Gopinath, C., \& Adeel, A. (2020). Impact of servant leadership on performance: The mediating role of affective and cognitive trust. SAGE Open January-March 2020, 1-16. Retrieved from https:// journals. sagepub.com/doi/10.117 7/2158244 019900562

Sedarmayanti (2017). Reformasi administrasi publik reformasi birokrasi dan kepemim pinan masa depan. Bandung: PT. Refika Aditama.

Shishigu, A. (2015). Factors affecting teachers' motivation and professionalism: The case of public primary schools in Addis Ababa, Ethiopia. The International Journal of Humanities \& Social Studies, 3(8), 140-146

Siagian, S. P. (2013). Manajemen sumber daya manusia. Jakarta: Bumi Aksara. 
Sihombing, S., Astuti, E., Al Musadieq, M., Hamied, D., \& Rahardjo, K. (2018). The effect of servant leadership on rewards, organizational culture and its implication for employee's performance. International Journal of Law and Management, $60(2), 505-516$.

Sinha, S., Singh, A. K., Gupta, N., \& Dutt, R. (2010). Impact of work culture on motivation and performance level of employees in private sector companies. Acta Oeconomica Pragensia, 6, 49-67.

Su, W., Lyu, B., Chen, H., \& Zhang, Y. (2020), How does servant leadership influence employees' service innovative behavior? The roles of intrinsic motivation and identification with the leader, Baltic Journal of Management, 15(4), 571-586. https://doi.org/10.1108/BJM-09-2019-0335.
Sugiarti, I., Suntoro, I., \& Nurmalisa, Y. (2015). The influence of work culture and work motivation on the performance of Village Apparatus in Tatakarya. Jurnal Kultur Demokrasi, 4(1), 1-12.

Terry, G. R. (2003). Prinsip-prinsip manajemen. Jakarta: PT. Bumi Aksara.

Virgana, V. (2020). The effect of job performance through organizational culture, work environment, personality, and motivation. Jurnal Manajemen dan Kewirausahaan, 22(2), 87-98.

Yumte, P., Rante, Y., Ronsumbre, J., \& Ratang, W. (2017). Influence of the servant leadership, organizational culture and employee motivation on work performance. Journal of Social and Development Sciences, 8(1), 13-19. 